\author{
Юлия Егорова \\ ORCID: 0000-0001-6037-0466
}

Институт мировой литературы им. А.М. Горького Российской академии наук Москва, Россия

\title{
Образ Фомы Гордеева в системе идейно- -эстетических исканий раннего Горького
}

\author{
https://doi.org/10.34739/clit.2021.15.09
}

\section{The Image of Foma Gordeev in the System of Ideological and Aesthetic Searching of Early Gorky}

\begin{abstract}
The story of Foma Gordeev summed up the period of Gorky's ideological and aesthetic search at the end 19th - early 2oth centuries, associated with the searching for a new hero in literature. The writer did not see in the representatives of the merchant dynasties people capable of building a worthy future for Russia. Even the presented image of the "atypical", "broken out" from the class of his own kind, Foma Gordeev, became similar to Gorky's "superfluous person", unable to become an active fighter for the reorganization of the world. In this work, Gorky depicted the collapse of the era of capitalist relations and marked a new upsurge in the labor movement for Russia and the growth of the ideas of socialism.
\end{abstract}

Keywords: Maxim Gorky, Foma Gordeev, the image of a merchant, merchants

Роман Фома Гордеев занимает особое место в раннем творчестве М. Горького, поскольку это одно из первых крупных и значительных его произведений, созданных в непростой период рубежа веков, период поиска новой эстетики, литературных форм и нового героя. Кроме того конец XIX века был отмечен непростой общественнополитической ситуацией в России, тесно переплетённой с судьбой Горького, что в конечном итоге повлияло на формирование его личности и писательского таланта.

В своей статье Русская литература “серебряного века” как сложная целостность Вс.А. Келдыш отмечает:

(...) в 1880-х гг. отчётливы предвестия грядущего обновления, с которым связано следующее десятилетие - переломное для бытия 
страны. 1890-е гг. постепенно формируют новое восприятие исторической действительности, о чем много говорили современники: осознание резко ускорившегося жизненного потока и нарастающие сомнения в устойчивости окружающего миропорядка. Глубоко всколыхнул их общественный подъём начала 1900-х гг., завершившийся событиями Первой русской революции 1905-07 гг.

Эти процессы - не прямо, сложно, опосредованно - воздействовали на логику художественного развития. (...) Для деятелей русской литературы было характерно в ту пору улавливать во впечатлениях, полученных от российской действительности, общемировой смысл1.

Ощущая требование времени, Горький чувствовал острую необходимость в экстренных переменах внутри себя, собственных взглядов и ориентиров. Говоря о влиянии 90-х гг. на его творчество, А.И. Овчаренко в книге Публицистика М.Горъкого пришёл к выводу:

(...) писатель был весь в мучительных поисках истины и путей борьбы за неё. При общей революционно-демократической и социалистической настроенности он не имел ясных и твёрдых взглядов по многим вопросам, и в миропонимании писателя временами боролись самые противоречивые тенденции ${ }^{2}$.

Период поиска новой эстетики и нового героя совпал у Горького со временем работы в конце весны - начале лета 1896 года на Всероссийской промышленной выставке и Всероссийском торговопромышленном съезде в Нижнем Новгороде, где и возникла мысль написать произведение, посвящённое русскому купечеству, а также, по мнению А.А. Тиховодова, «(...) обличению господствующих, но уходящих классов России», где в центре внимания «(...) судьбы масс и незаурядной личности, вступившей в глубокий конфликт с “хозяевами” жизни накануне решительных перемен в обществе»3. Поставленная автором проблема, продолжает Тиховодов, отвечала требованиям времени:

\footnotetext{
${ }^{1}$ В.А. Келдыш, Русская литература «серебряного века» как сложная целостность, [в:] Русская литература рубежа веков (1890-е - нач. 1920-х г2.), Кн. 1, Москва 2000, с. 13.

2 А.И. Овчаренко, Публицистика М. Горького, изд. 2-е, Москва 1965, с. 53.

3 А.А. Тиховодов, Процесс «выламывания» в «Воскресении» Л. Толстого и «Фоме Гордееве» М. Горького, [в:] Горьковский сборник (К 1оо-летию со дня рождения М. Горького) /Учёные записки, Вып. 11, Горький 1968, с. 106-107.
} 
Отщепенство незаурядного человека от своей социальной среды, его «восхождение к верхам» или «нисхождение к низам» общества, его разрыв с идеалами трудового народа или приближение к ним, его «духовное обнищание», очерствение души или «воскресение» её (...) отражено в русской и мировой литературе XVIII и XIX столетий ${ }^{4}$.

Находясь в гуще событий обоих форумов, Горький получил аккредитацию в качестве специального корреспондента «Одесских новостей» и представителя «Нижегородского листка». Уже через несколько дней после приезда, а именно - 20 мая, Горьким был написан первый фельетон $O$ благоустройстве $H$. Новгорода. Об оживлении промышленной жизни города и др. Неделю спустя его опубликовали в «Одесских новостях», тогда же на страницах газеты был проанонсирован цикл фельетонов C Всероссийской выставки (впечатления, наблюдения, наброски, сцены и т.д.). В этих заметках и набросках Горький размышлял о прошлом русского купечества, «о путях и способах завоевания им „места под солнцем”, о его роли в историческом развитии России»5. В рамках обоих мероприятий Горький имел возможность посещать заседания съезда, где поднимались вопросы внешней торговли, таможенной и финансовой политики. Он с неподдельным интересом наблюдал за представителями крупной промышленности, банкирами, купцами, финансовыми воротилами, съехавшимся в Нижний Новгород со всей России. Полученные впечатления наложились на многолетние наблюдения Горького за жизнью купцов Поволжья, в первую очередь - Нижнего Новгорода, Казани, Самары. По собственному признанию, именно 1896 год, работа на промышленной выставке дала богатый материал для понимания, кто такие «хозяева» жизни. Знакомство с промышленниками и меценатами С. Мамонтовым, С. Морозовым; купцами-миллионерами Башкировым, Н.А. Бугровым; заводчиком А. Зарубиным; выходцем из ветлужских крестьян купцом Гордеем Черновым, известным «своими революционными изобретениями, непредсказуемыми поступками, умопомрачительными сделками» 6 , вызвало в сознании Горького образы больших человеческих

\footnotetext{
4 Ibidem, c. 107.

5 М. Горький, Полное собрание сочинений. Художественные произведения в 25 томах, Т. 4, Москва 1969, с. 587. Далее - ПСС. Сочинения.

6 А.Ю. Чернов, С.М. Глухова, Волжский купец Гордей Чернов, “Национальные приоритеты России" 2020, № 1 (36), с. 28.
} 
характеров. «Новые хозяева жизни» вызывали неподдельное любопытство у начинающего писателя, его занимала «внешняя и внутренняя сторона заинтересовавшего персонажа, и он осматривал, ощупывал и облюбовывал со всех сторон, с приёмами живописца и скульптора, и притом брал его в соответствующей обстановке, всматриваясь одновременно во внутреннюю сущность, - вспоминал белорусский историк А.В. Богданович. - Оценка социального значения возникала уже потом, в результате всестороннего изучения»7. Впечатления от общения с финансовыми воротилами и промышленниками, наблюдения за личной жизнью и общественной деятельностью купцов-миллионеров, а также наблюдения, накопленные за время странствий по центральной России, Горький ввёл в сюжет повести. Некоторые представители крупных торговых династий стали прототипами Якова Маякина, Щурова и Игната и Фомы Гордеева. По мнению исследователей творчества Горького Н. Белкиной, Я. Зунделович, Б. Михайловского, В. Ланина, А. Тарасовой и др., наиболее вероятным прототипом последних стал купец Гордей Чернов. Несколько ярких эпизодов из жизни «короля Волги», его эксцентричные выходки, поразившие Горького, нашли отражение в развитии сюжетных линий отца и сына Игната и Фомы Гордеевых. Примером может служить реальный случай с гибелью барж во время весеннего половодья, описанный в повести, а также отдельные эпизоды из жизни купца Чернова:

\section{Реальные события:}

Весенним ледоходом срезало его [Гордея Чернова - E.Ю.] нефтяной караван, стоявший в Сормовском затоне. Разбились и пошли ко дну двадцать больших барж. Чернов, наблюдавший катастрофу с городского берега, проявил удивительное хладнокровие и самообладание. «Бог дал, Бог и взял», - произнёс он тихим голосом и отправился на Курбатовский завод... заказывать новый, грандиозный, невиданной величины буксирный пароход в 2400 лошадиных сил 8 .

\footnotetext{
7 А.В. Богданович, Из жизни Алексея Максимовича Пешкова. Нижегородский период (1896-1904), Горький 1968, с. 79-80.

8 Ibidem, c. 30.
} 


\section{События повести:}

Однажды, во время ледохода на Волге, он [Игнат Гордеев - E.Ю.] стоял на берегу и, видя, как лёд ломает его новую тридцатипятисаженную баржу, притиснув её к обрывистому берегу, приговаривал сквозь зубы: - Так её!.. Ну-ка ещё... жми-дави! (...) Ты гляди, как работает Волга-то! (...) Она, матушка, всю землю может разворотить, как творог ножом, (...) - Жалко посуду-то, Игнат? - спросил Маякин.

- Ну, чего ж жалеть? Волга дала, Волга и взяла... Чай не руки мне оторвало...9

\section{Кутежи Гордея Чернова:}

Нажитые в короткое время миллионы вскружили Гордею голову, он начал «маяться и куролесить». О его сногсшибательных тратах и кутежах, сопровождавшихся необузданным озорством и самодурством, заговорили по всей Волге. ${ }^{10}$

После каждого запоя Гордей заказывал молебен, окроплялся святой водой и жил «по-человечески» два-три месяца, а потом вновь возвращался на круги своя ${ }^{11}$.

\section{Кутежи Игната Гордеева:}

Дерзкий со всеми и циничный, он пил, развратничал и спаивал других, он приходил в исступление, и в нём точно вулкан грязи вскипал. (...) О его кутежах в городе создавались легенды, его строго осуждали, но никто никогда не отказывался от его приглашения на оргии. Так он жил неделями. И неожиданно являлся домой ещё весь пропитанный запахом кабаков, но уже подавленный и тихий. Со смиренно опущенными глазами, в которых теперь горел стыд, он молча слушал упрёки жены (...). По несколько часов кряду он выстаивал на коленях пред образами, опустив голову на грудь; (...) и он молчал, как бы не смея молиться ${ }^{12}$.

Горького заинтересовал не только процесс становления класса русской буржуазии и его роста, но более всего - его разложения. И вот тогда писателя посетила мысль создать произведение, раскрывающее все перечисленные этапы.

Впервые о желании написать роман на эту тему и о начале работы над ним Горький высказался в письмах к А.Л. Волынскому, датированных августом и сентябрём 1897 г.: «Вот я скоро перестану

\footnotetext{
9 М. Горький, ПСС. Сочинения, с. 184.

10 В. Блохина, Л. Либединская, Горький в родном городе, Москва 1972, с. 3.

${ }^{11}$ А.Ю. Чернов, С.М. Глухова, op. cit., с. 29.

12 М. Горький, ПСС. Сочинения, с. 185, 186.
} 
изображать моих босяков - моих „учителей жизни” - и возьмусь за другой класс людей, тоже знакомых мне», «Теперь я намерен заняться вещью более широкого значения (...)»13. Однако за активную работу писатель взялся через год, в октябре 1898 г., а уже в августе 1899 г. он сообщил в письме А.П. Чехову: «Фому дописал и очень рад»14. В этом же письме Горький спрашивал у писателя разрешения посвятить ему эту книгу: «Антон Павлович! Разрешите мне посвятить Вам Фому в отдельном издании? Если это будет Вам приятно - разрешите, пожалуйста. Не будет - так и скажите - не надо. Я не самолюбив, и Ваш отказ отнюдь не обидит меня»15. В этом же году произведение вышло в свет.

Согласно первоначальному замыслу, повесть называлась Игнат Гордеев, о чем свидетельствует письмо В.А. Поссе к Горькому от 23 января 1899 г. Высказывая автору своё мнение о начале повести, Поссе писал: «Зачем ему [роману] зваться Игнатом? Ведь суть в конце концов будет в Фоме?» ${ }^{16}$ Судя по тому что произведение вышло в свет под названием Фома Гордеев, Горький принял предложение и согласился с ним.

Лишь в процессе работы писатель окончательно определился с замыслом, первое крупное эпическое произведение обрело свою идейную направленность. В феврале 1899 г. Горький писал Дороватовскому:

Эта повесть - доставляет мне немало хороших минут и очень много страха и сомнений, - она должна быть широкой, содержательной картиной современности, и в то же время на фоне её должен бешено биться энергичный, здоровый человек, ищущий простора своей энергии. Ему тесно, жизнь давит его, он видит, что героям в ней нет места, их сваливают с ног мелочи, как Геркулеса, побеждавшего гидр [и львов], свалила бы с ног туча комаров. Выйдет ли у меня это достаточно ярко и понятно?17

Повесть представляется Горькому, как произведение о «нетипическом купце», нетипическом с точки зрения буржуазии, однако уже

\footnotetext{
13 М. Горький, Полное собрание сочинений. Письма, Т. 1. Москва 1997, с. 229, 236. Далее - ПСС. Письма.

14 Ibidem, c. 355 .

15 Ibidem, c. 354 .

${ }^{16}$ Архив А.М. Горького. КГ-п-59-1-36.

17 М. Горький, ПСС. Писъма, Т. 1, с. 310.
} 
нередком явлении во втором или третьем поколении буржуа. В первой (1899 г. - журнал «Жизнь») и последующих трёх редакциях (1900 г. первое отдельное издание; 1903 г. - издание «Знание»; 1923 г. берлинское издание) в произведении намечены два полюса: Яков Маякин и Фома Гордеев. Первый олицетворяет собой представителя российского купечества, умного и хитрого, по-настоящему опытного. Второй - молодой, начинающий предприниматель, человек, который

(...) «выломился» из «нормального строя жизни», сильный и честный человек, но ещё не нашедший себе места в жизни, ещё не определивший своего собственного пути. Между ними располагаются все остальные персонажи: Тарас и Любовь Маякины, Игнат и Наталья Гордеевы, Ананий Щуров, Ежов, Саша, Медынская, купцы - каждый занимает своё место в книге, каждый выполняет самостоятельную роль, но в то же время раскрывает характер Фомы в его взаимоотношениях с людьми, жизненных связях и противоречиях. По ходу действия романа они то приближаются к Фоме и удаляются от Якова, то наоборот ${ }^{18}$.

В конце книги Фома остаётся один, поверженный и разбитый. Яков Маякин одерживает победу, но победа эта временная, кажущаяся, поскольку такие «выламывающиеся», как Фома, подрывают класс купечества изнутри, ослабляют его и подводят к разложению и, как следствие, к гибели.

Как было сказано выше, повесть имела четыре редакции, работа и редактура над ней протянулась почти в двадцать пять лет, однако в окончательном варианте, вышедшем в 1923 г., произведение сильно не изменилось. Тема и первоначальный авторский замысел, выраженный в письме С.П. Дороватовскому, остались неизменны, всё задуманное автором нашло отражение в характерах героев и прежде всего Фомы. В одной из финальных сцен, разворачивающейся на пароходе купца Кононова, когда собравшиеся хватают и вяжут Фому, бросившего каждому гневное обличение и высказавшего правду в лицо, звучит основная идея произведения: «Я понимаю, чего хотел. Хотел сказать правду... Хотел обличить вас... (...) И хоть слаба моя правда против вас, а всё-таки - правда!» ${ }^{19}$

Как уже было сказано, в образной системе произведения есть два полюса: Яков Маякин и Фома Гордеев. Тем не менее главным

${ }^{18}$ Н. Белкина, В творческой лаборатории М. Горького, Москва 1940, с. 43.

19 М. Горький, ПСС. Сочинения, с. 453, 455 . 
героем является именно Фома, так как развитием этого персонажа определяется содержание произведения. Автор раскрывает перед читателем всю жизнь героя: от момента ожидания его появления на свет, когда Игнат жаждет сына - наследника его состояния и продолжателя дела; далее писатель проводит нас через этапы детства Фомы в доме Маякина, школьные годы, приезд Анфисы, сестры Игната, её участие в воспитании племянника, и годы взросления. Образ Анфисы Гордеевой очень напоминает бабушку Акулину самого автора. Прекрасной души человек, набожная, добрая и мягкая, она была антиподом жестокому деду Каширину. Она знакомила маленького Алёшу Пешкова с миром народных сказок, песен. Благодаря ей, он познакомился с неведомыми доселе старинными сказаниями о сильных, слабых и добрых людях. Анфиса, такая же кроткая, спокойная и истинно религиозная, как и бабушка Акулина, оказала бесспорное влияние на племянника и попыталась привить ему эти же качества. Воспоминания о бабушке, пожалуй, единственном добром друге своего детства, Горький воплотил в образе тётки Анфисы.

Фома Гордеев относится уже ко второму поколению буржуазии. Широта помыслов и поступков Игната, сила и мощь его натуры не нашли воплощения в сыне в том объёме, в каком он желал. Мать Фомы - старообрядка Наталья - была чужой в доме мужа. Она словно отгородилась от жизни, ушла в себя. Единственное, что женщина успела передать в наследство сыну, это выраженное сознание того, что жизнь эта ненастоящая, ненужная. По натуре кроткая и терпеливая, но вместе с тем волевая, Наталья наделила Фому характером бунтаря. Этот персонаж развивается в определённых жизненных связях. Поскольку мать умирает во время родов, связь с ней остаётся лишь наследственными чертами в сыне. Иная ситуация с Игнатом. Он умирает в период становления сына, когда Фома совершил первую самостоятельную поездку на пароходе.

Повесть Фома Гордеев подвела итог периоду идейноэстетических исканий Горького конца XIX - начала XX века, связанных с поиском нового героя в литературе. По мнению Джека Лондона, писавшего о Фоме Гордееве в 1901 году: «Эта книга действенное средство, чтобы пробудить дремлющую совесть людей 
и вовлечь их в борьбу за человечество» ${ }^{20}$. Американский писатель увидел в новаторство Горького в том, что тот изобразил активность «подлинно русского человека», несущего людям «правду», пусть и «тяжеловесную, грубую». Главное, что отметил Дж. Лондон в книге молодого писателя, это: «самонаблюдение и углублённый самоанализ, характерные для русских», а также протест «против социальной несправедливости, против унижения бедных и слабых, против озверения богатых и сильных в бешеной погоне за влиянием и властью 21 . Несмотря на положительные отклики, сам автор не увидел в представителях купеческих династий людей, способных построить достойное будущее для России. Даже представленный образ «нетипичного», «выломившегося» из класса себе подобных Фомы Гордеева стал похож у Горького на «лишнего человека», не способного стать активным борцом за переустройство мира. В этом произведении Горький изобразил распад эпохи капиталистических отношений и обозначил новый для России подъём рабочего движения и рост идей социализма.

\section{Литература}

Архив А.М. Горького. КГ-п-59-1-36.

Белкина Н., В творческой лаборатории М. Горького, Москва 1940.

Блохина В., Либединская Л., Горький в родном городе, Москва 1972.

Богданович А.В., Из жизни Алексея Максимовича Пешкова. Нижегородский период (1896-1904), Горький 1968.

Горький М., Полное собрание сочинений. Письма, Москва 1997.

Горький М., Полное собрание сочинений. Художественные произведения в 25 томах, Москва 1969.

Келдыш В.А., Русская литература «серебряного века» как сложная целостность, [в:] Русская литература рубежа веков (189о-е - нач. 1920-х г2.), Кн. 1, Москва 2000.

Лондон Д., Собр. соч. в 14 mm., Т. 6, Москва 1961.

Овчаренко А.И., Публицистика М. Горького. Изд. 2-е, Москва 1965.

Тиховодов А.А., Процесс «выламывания» в «Воскресении» Л. Толстого и «Фоме Гордееве» М. Горького, [в:] Горьковский сборник (К 10о-летию со дня рождения М. Горького). Учёные записки, Вып. 110, Горький 1968.

Чернов А.Ю., Глухова С.М., Волжский купец Гордей Чернов, “Национальные приоритеты России" 2020, № 1 (36).

20 Д. Лондон, Собр. соч. 814 mm., Т. 6, Москва 1961, с. 22.

${ }^{21}$ Ibidem, c. 29. 


\section{References}

Arhiv Gor'kogo, KG-p-59-1-36.

Belkina N., V tvorčeskoj laboratorii M. Gor'kogo, Moskva 1940.

Blohina V., Libedinskaâ L., Gor'kij v rodnom gorode, Moskva 1972.

Bogdanovič A.V., Iz žizni Alekseâ Maksimoviča Peškova. Nižegorodskij period (1896-1904), Gor'kij 1968.

Gor'kij M., Polnoe sobranie sočinenij. Pis'ma, Moskva 1997.

Gor'kij M., Polnoe sobranie sočinenij. Hudožestvennye proizvedeniâ v 25 tomah, Moskva 1969.

Keldyš V.A., Russkaâ literatura «serebrânogo veka» kak složnaâ celostnost', [v:] Russkaâ literatura rubeža vekov (1890-e - nač. 1920-h gg.), Kn. 1, Moskva 2000.

London D., Sobr. soč. v 14 tt., T. 6, Moskva 1961.

Ovčarenko A.I., Publicistika M. Gor'kogo. Izd. 2-e, Moskva 1965.

Tihovodov A.A., Process «vylamyvaniâ» $v$ «Voskresenii» L. Tolstogo $i$ «Fome Gordeeve» M. Gor'kogo, [v:] Gor'kovskij sbornik (K 10o-letiû so dnâ roždeniâ M. Gor'kogo). Učënye zapiski, Vyp. 110, Gor'kij 1968.

Černov A.Û., Gluhova S.M., Volžskij kupec Gordej Černov, „Nacional'nye prioritety Rossii” 2020, № 1, (36). 